\title{
Linkage analysis in the spinal muscular atrophy type of facioscapulohumeral disease
}

\author{
TEEPU SIDDIQUE*, HELEN ROPER $\dagger$, MARGARET A PERICAK-VANCE*, \\ JOHN SHAW + , KATHERINE L WARNER*, WU-YEN HUNG*, \\ KENNETH L PHILLIPS*, PETER LUNT $\ddagger$, W J KENNETH CUMMING*, AND \\ ALLEN D ROSES*
}

From *the Division of Neurology, Department of Medicine, Duke University Medical Center, Durham, North Carolina 27710, USA; †University Hospital of South Manchester, Withington Hospital, Manchester; and $¥$ St Mary’s Hospital, Manchester.

SUMMARY Facioscapulohumeral disease is probably a heterogeneous disorder. We have ascertained and sampled two multigeneration families with the neurogenic form of this disorder, considered to be a type of spinal muscular atrophy (FSHSMA). The two families have 36 affected members. Linkage studies with 10 expressed and seven DNA restriction fragment length polymorphism (RFLP) markers failed to show significant linkage $\left(Z_{\max } \geqslant 3.00\right)$. However, two areas of probable linkage were defined on chromosomes $1 p$ and $4 q$ with the markers MNS $\left(Z_{\max }=1.47\right.$ at $\left.\theta_{\max }=0.10\right)$ and PGM1 $\left(Z_{\max }=0.94\right.$ at $\left.\theta_{\max }=0.001\right)$ respectively. We are using additional RFLPs from these and other areas of the human genome to screen these families for linkage to FSHSMA.

A number of neuromuscular disorders present as facioscapulohumeral disease (FSHD) and have been grouped together because of a common distribution of muscle weakness. The first hint of heterogeneity came in 1885 when Landouzy and Déjérine drew attention to the presence of fasciculations in patients with FSHD. ${ }^{1}$ Since then, several other investigators have noted muscle atrophy and fasciculations ${ }^{2}$ as well as changes of denervation and reinnervation on muscle biopsy ${ }^{3}$ and on electromyographic examination $^{45}$ in some patients presenting with muscular weakness in the FSH distribution. This type of FSHD is thus considered to be a form of spinal muscular atrophy (FSHSMA). Occasionally the myopathic form of the disease has been shown to be an inflammatory myopathy ${ }^{6}$ or a mitochondrial myopathy ${ }^{8}$ observed in a familial setting.

The neurogenic or spinal muscular atrophy form of FSH (FSHSMA) is usually inherited as an autosomal dominant disorder. ${ }^{34}$ We have ascertained two large multigeneration families with this disorder and analysed them for linkage to 17 markers.

\section{Material and methods}

Two families (figure $a$ and $b$ ) were ascertained through affected probands and examined by at least one of us (HR, JS, PL, or WJKC). Muscle biopsy of probands and other affected members are compatible with a chronic denervating and reinnervating process, manifested by scattered atrophic angulated fibres and grouping of fibre types.

There are 36 affected subjects in these families and DNA has been banked from 46 subjects (figure). Ten expressed (Rh, PGM1, Fy, ACP1, MNS, P, ABO, Hap, Jk, and Kell) and seven DNA [NGF, hEGF(121)(EGF), JJ11-1(FGFB), pE7 (EGFR)NGFR(PE51), GSM21(D21S13), and pS2 (BCEI)] markers were studied in these families (table).

High molecular weight genomic DNA was extracted from whole blood or from Epstein-Barr virus transformed cell lines as previously described. ${ }^{9}$ DNA restriction fragment length polymorphism (RFLP) analysis was performed on genomic DNA using standard methods of DNA digestion, gel electrophoresis, Southern blotting, probe hybridisation, and autoradiography. ${ }^{9}$ Standard methods were used for expressed marker analysis.

Linkage analysis was performed using the computer program LIPED. ${ }^{10}$ The FSHSMA gene was 


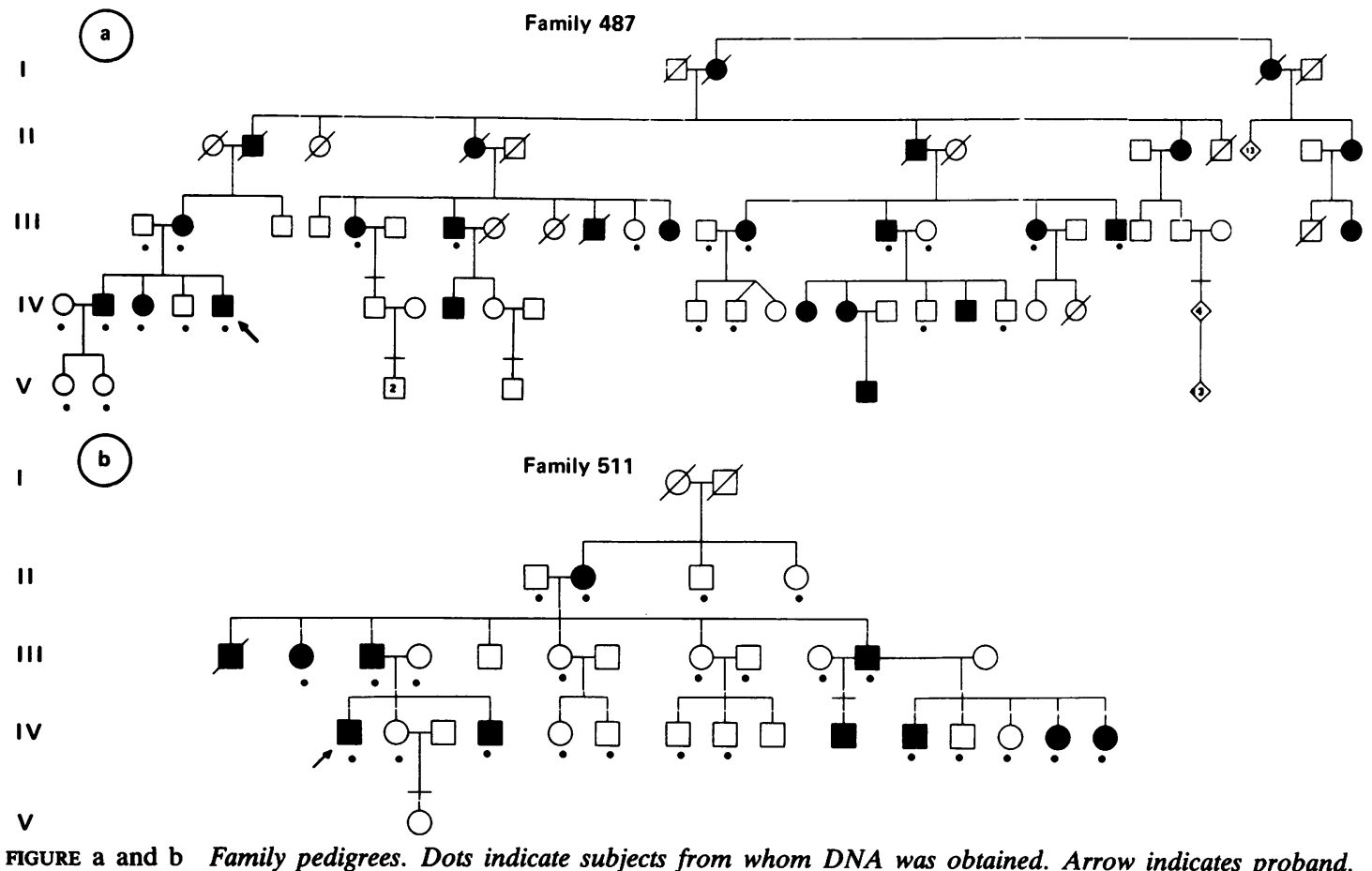

puter program LIPED. ${ }^{10}$ The FSHSMA gene was assumed to be autosomal dominant with age dependent penetrance. The age curve used in the analysis was based on the data of Lunt $\mathrm{et} \mathrm{al}^{11}$ and resulted in a penetrance of 0.95 by age 20 . Equal recombination between males and females was assumed between the FSHSMA and the marker loci. The gene frequencies used for the marker loci were based on reported frequencies. ${ }^{12-14}$

\section{Results}

The results of the lod scores are given in the table. Linkage $\left(\log _{10}\right.$ odds ratio of +3$)$ was not established with any of the tested markers. However, tight linkage $(\theta \geqslant 0.001)$ could be excluded for $R h, J k$, and $\mathrm{hEGF}(121)$ and is nearing exclusion for pS2(BCEI). The highest lod score obtained was for MNS $\left(Z_{\max }=1.47\right.$ at $\left.\theta_{\max }=0 \cdot 10\right)$, while $\mathrm{JJ} 11-1$ (FGF8)

TABLE Marker to marker lod scores for facioscapulohumeral spinal muscular atrophy.

\begin{tabular}{|c|c|c|c|c|c|c|c|c|}
\hline \multirow[t]{2}{*}{ Marker } & \multirow[t]{2}{*}{$\begin{array}{l}\text { Chromosomal } \\
\text { location }\end{array}$} & \multicolumn{7}{|l|}{$\begin{array}{l}\theta m=\theta f \\
\theta\end{array}$} \\
\hline & & 0.001 & 0.05 & $0 \cdot 10$ & 0.15 & 0.20 & 0.30 & 0.40 \\
\hline $\mathbf{R h}$ & $1 p 36.2-p 34$ & -2.54 & -0.70 & -0.36 & -0.19 & -0.10 & -0.02 & 0.00 \\
\hline PGM1 & $1 \mathrm{p} 22.1$ & 0.94 & 0.83 & 0.71 & 0.59 & 0.46 & 0.23 & 0.06 \\
\hline NGF & $1 p 22.1$ & -0.66 & -0.19 & -0.04 & 0.15 & 0.19 & 0.17 & 0.06 \\
\hline Fy. & $1 p 21-q 23$ & 0.06 & 0.06 & 0.05 & 0.05 & 0.04 & 0.02 & 0.01 \\
\hline MNS & $4 q 28-q 31$ & $-1 \cdot 85$ & 1.20 & 1.47 & 1.47 & 1.35 & 0.94 & 0.42 \\
\hline JJ11-1 & 4q21-qter & 0.69 & 0.61 & 0.52 & 0.43 & 0.34 & $0 \cdot 18$ & 0.05 \\
\hline EGF & 4925 & -6.73 & -1.61 & -0.80 & -0.42 & -0.21 & -0.06 & -0.03 \\
\hline pE7 & 7p13-p12 & $-5 \cdot 56$ & -1.90 & $-1 \cdot 13$ & -0.71 & -0.46 & $-0 \cdot 17$ & -0.04 \\
\hline $\mathbf{P}$ & 6 & -0.63 & -0.49 & -0.37 & -0.28 & -0.20 & -0.08 & -0.02 \\
\hline ABO & $9 q 34$ & -0.12 & -0.08 & -0.05 & -0.03 & -0.02 & 0.00 & 0.00 \\
\hline Hap & $16 \mathrm{q} 22.1$ & -0.25 & -0.15 & -0.09 & -0.05 & -0.03 & 0.01 & 0.00 \\
\hline pE51 & $17 q 22$ & 0.16 & 0.33 & 0.38 & 0.38 & 0.35 & 0.23 & 0.08 \\
\hline Jk & $18 q_{11-q 12}$ & $-2 \cdot 00$ & -0.39 & -0.18 & -0.08 & -0.03 & 0.00 & 0.00 \\
\hline
\end{tabular}


gave a $Z_{\max }$ of 0.69 at $\theta_{\max }$ of 0.001 . PGM1 gave a lod score $\left(Z_{\max }\right)$ of 0.94 at $\theta_{\max }$ of 0.001 . Kell and GMS21 (D21S13) were uninformative.

\section{Discussion}

The debate about whether autosomal dominant FSHD is a heterogeneous disorder, consisting of at least a neurogenic and a myopathic form, or if it is a disease of the motor unit that manifests both phenotypes, has not been resolved by clinical investigation. This debate would be resolved if linkage is established in either the myopathic or the neurogenic form of FSHD; the linked markers can then be tested in the other group. In this report linkage was tested between the FSHSMA locus and 16 markers in two FSHD families who had convincing evidence of a neurogenic process. Even though linkage was not established, areas suggestive of linkage were identified on chromosome $4 q$ and $1 p$ (table). Two markers on $4 \mathrm{q}$ (MNS and JJ11-1) and one on 1p22.1 (PGM1) indicate areas of probable linkage. However, NGF, another marker on 1p22.1, does not support the latter probability. Clearly, additional probes from $1 p$ and $4 q$ need to be tested in the present families, and additional FSHSMA families included in the study to establish or exclude linkage from these regions.

This study was supported by grants from the Muscular Dystrophy Association of America (TS) and the National Institutes of Health [K07 NS0096004 and P01-NS21442 (TS)]. We thank Jackie Bebout for help with computer analysis of linkage data, Helen Harbett and Peggy Pate for entry of genotype data, and Tina Brantley for typing this manuscript and preparing the artwork for the figure. We thank the following investigators for sharing their DNA RFLP probes with us: M V Chao for PE51, G Bell for hEGF(121), J Abraham of Cal Bio for JJ11-1, and Gordon D Stewart for GSM21. NGF, pE7, and
PS2(BCEI) were obtained from ATCC where they were deposited by A Ullrich, G Merlino, and P Chambon, respectively.

\section{References}

${ }^{1}$ Landouzy L, Déjérine J. De la myopathie atrophique progressive. Rev Med 1885;5:81-117, 253-366; 1886; 6:977-1027.

2 Benassi P, Canestrari P. Su una particolare forma de la distrofia muscolare tipo Landouzy-Dejerine. Riv Patol Nerv Ment 1953; 74:435-48.

${ }^{3}$ Fenichel GM, Emery ES, Hunt P. Neurogenic atrophy simulating facioscapulohumeral dystrophy. Arch Neurol 1967;17:257-60.

4 Furukawa T, Toyokura Y. Chronic spinal muscular atrophy of facioscapulohumeral type. J Med Genet 1976;13:285-9.

5 Kazakov VM, Kovalenko TM, Skorometz AA, Mikhailov EP. Chronic spinal muscular atrophy simulating facioscapulohumeral type and limb-girdle type of muscular dystrophy. Eur Neurol 1977;16:90-8.

${ }^{6}$ Rothstein TL, Carlson CB, Sumi SM. Polymyositis with FSH distribution. Arch Neurol 1971;25:313-9.

${ }^{7}$ Munsat TL, Piper D, Cancilla P, Mednick J. Inflammatory myopathy with FSH distribution. Neurology (Minneap) 1972;22: 335-47.

${ }^{8}$ Hudgson P, Bradley WG, Jenkinson M. Familial mitochondrial myopathy. Part I, clinical, electrophysiological and pathological findings. J Neurol Sci 1972;16:343-70.

9 Siddique T, McKinney R, Hung WY, et al. The poliovirus sensitivity (PVS) gene is on chromosome 19q12-q13.2. Genomics 1988;3:156-60.

$10 \mathrm{Ott}$ J. Estimation of the recombination fraction in human pedigrees: efficient computation of the likelihood for human linkage studies. Am J Hum Genet 1974;26:588-97.

1 Lunt PW, Noades JG, Upadhyaya M, Sarfarazı M, Harper PS. Evidence against location of the gene for facioscapulohumeral muscular dystrophy on the distal long arm of chromosome 14. J Neurol Sci 1988;88:287-92.

12 Cavalli-Sforza LL, Bodmer WF. The genetics of human populations. San Francisco: Freeman, 1971:724-33.

13 Mourant AE, Kopec AC, Domaniewska-Sobczak K. The distribution of the human blood groups and other polymorphisms. London: Oxford University Press, 1976.

14 Pearson PL, Kidd KK, Willard F. Report of the committee on human gene mapping by recombinant DNA techniques. Cytogenet Cell Genet 1987;46:390-566.

Correspondence to Dr Teepu Siddique, Division of Neurology, Box 2900, Research Park I, Duke University Medical Center, Durham, North Carolina 27710, USA. 